\title{
Kryzys gospodarczy w Bośni i Hercegowinie i jego wpływ na stabilność państwa (wybrane aspekty)
}

Bośnia i Hercegowina (BiH) od 2009 r. znajduje się w stanie głębokiego kryzysu ekonomicznego i społecznego. W mniejszym stopniu jest on rezultatem światowego kryzysu finansowego (choć jego negatywnego wpływu nie można nie zauważać), a w większym - wynikiem braku woli i umiejętności miejscowych władz przy przeprowadzaniu koniecznych reform ${ }^{1}$. Państwo, którego aktualny kształt ustrojowy, społeczny i gospodarczy tak naprawdę został ponownie zdefiniowany w $1995 \mathrm{r}$., i to przez podmioty zewnętrzne, nie otrząsnęło się jeszcze $\mathrm{z}$ traumy wojny, a ponownie popadło w poważne problemy zagrażające bezpieczeństwu i stabilności wewnętrznej.

Trzeba w tym miejscu podkreślić, że kryzys nie jest dla obywateli Bośni i Hercegowiny niczym nadzwyczajnym. Jak pisze Rajko Tomaš, różne formy kryzysu i jego różne natężenie sq tu obecne od lat. Mieszkańcy sa przyzwyczajeni do ciężkiego życia, niepewności, niskiego standardu, izolacji, politycznej niestabilności, niskiego poziomu usług publicznych, złej infrastruktury, korupcji, nieefektywności organów państwowych, tamania prawa, ograniczenia wolności, utraty pracy. [...] Kryzys

${ }^{1}$ T. Slijepčević [et al.], NVO sektor u BiH i podrška stranih donatora: (ne)naučene lekcije, „Forum Bosnae” 2013, br. 61-62, s. 25. 
w Bośni i Hercegowinie stał sie środowiskiem, w którym się żyje, otoczeniem, przez które patrzy się na świat, na reformy, na przysztość ${ }^{2}$.

Mimo takiego podejścia do rzeczywistości, sytuacja, która ma miejsce w tym kraju od 2009 r., jest postrzegana w porównaniu do wcześniejszych kilkunastu lat, mimo wszystko, jako coś wyjątkowego. Po raz pierwszy bowiem od wojny poziom życia mieszkańców - i tak przecież bardzo niski, jak na standardy państwa europejskiego - obniżył się, co wzmogło ogólnie fatalne postrzeganie własnego kraju. Kraju - co trzeba dodać - z którym nie wszyscy mieszkańcy w równym stopniu się utożsamiaja.

W niniejszym artykule główna uwaga skupiona jest na najważniejszych kwestiach gospodarczych oraz na tym, jaki wpływ wywieraja one na relacje społeczno-polityczne w Bośni i Hercegowinie. Ze względu na skomplikowaną materię i ogrom problemów z cała pewnością nie zostanie wyczerpane to zagadnienie. Pozostanie zatem pole do dalszych, pogłębionych badań.

\section{Wojna z lat 1992-1995 i jej skutki dla gospodarki Bośni i Hercegowiny}

Bośnia i Hercegowina w czasach socjalistycznej Jugosławii notowała relatywnie wysoki poziom rozwoju gospodarczego. Gdy kończyła się II wojna światowa, dominująca gałęzią gospodarki na tym obszarze było rolnictwo, a przemysł - zniszczony w wyniku działań zbrojnych - odgrywał niewielką rolę. Tym bardziej warto odnotować, że w 1990 r. rolnictwo

${ }^{2}$ R. Tomaš, Kriza i siva ekonomija u Bosni $i$ Hercegovini, Sarajevo 2010, s. 13. 
(wraz z rybołówstwem) stanowiło już tylko 9,46\% PKB Socjalistycznej Republiki Bośni i Hercegowiny, podczas gdy przemysł ciężki (wraz z górnictwem) wytwarzał aż 43,43\%³.

Jugosławia po II wojnie światowej była krajem szybko się rozwijającym. Trzeba jednak podkreślić, że jej poszczególne częśsi składowe, czyli republiki, różniły się między sobą tempem wzrostu. Jak pokazuja badania, w latach 1952-1984 (czyli do momentu, gdy kraj wpadł w głęboki kryzys gospodarczy) zdecydowanie największy przyrost PKB miał miejsce w Słowenii (279\%) oraz Chorwacji (236\%). Nieźle na tym tle wypadła także Bośnia i Hercegowina ze wzrostem na poziomie 184\% - ustapiła nieznacznie Serbii (200\%). Pozostałe podmioty federacji zanotowały gorsze rezultaty (Macedonia - 155\% i Czarnogóra - 144\%).

Gdy w 1990 r. rozpoczęła się końcowa faza procesu dezintegracji Jugosławii, kraj ten - mimo kryzysu ekonomicznego - znajdował się w o wiele lepszej sytuacji niż większość państw socjalistycznych, w których właśnie podjęto proces restrukturyzacji niewydolnej gospodarki. Poziom życia obywateli federacji jugosłowiańskiej był bowiem znacznie wyższy, a dobre relacje $\mathrm{z}$ krajami zachodnimi pozwalały na utrzymywanie kontaktów w zakresie stosowania względnie nowoczesnych technologii. Wraz z rozpoczęciem wojny - w najmniejszym stopniu w Słowenii, w większym w Chorwacji i największym w Bośni i Hercegowinie - ta sytuacja uległa dramatycznej zmianie ${ }^{5}$.

${ }^{3}$ F. Čaušević, Makroekonomski okvir strategije ekonomskog razvoja Bosne i Hercegovine, „Forum Bosnae” 2013, br. 63-64, s. 32.

${ }^{4}$ J. Osmanković, J. Hošo, E. Resić, Economic Development Model of the Western Balkans, „Posebna izdanja Akademije nauka i umjetnosti BiH” 2011, br. 2, s. 319.

${ }^{5}$ B. Tihi, Globalna ekonomska kriza, političke nesigurnosti i mogućnosti za reforme u Bosni i Hercegovini, [w:] Međunarodni simpozij Bosna 
Jeszcze w 1990 r. w BiH rozpoczą się proces prywatyzacji majątku państwowego. Wcześniej zakłady produkcyjne były własnością społeczna, która - według partyjnej propagandy - zarządzali robotnicy za pośrednictwem swoich przedstawicieli $w$ radach pracowniczych ${ }^{6}$. Na obszarze republiki znajdowało się ponad 1500 przedsiębiorstw produkcyjnych, które zatrudniały niemal pół miliona pracowników (47\% wszystkich zatrudnionych). Głównymi ośrodkami przemysłowymi były: Sarajewo, Zenica, Tuzla, Mostar, Zvornik, Jajce i Maglaj.

Po tragicznych wydarzeniach z lat 1992-1995 Bośnia i Hercegowina znalazła się $\mathrm{w}$ obliczu katastrofy gospodarczo-ekonomicznej. Poziom PKB per capita spadł z około 2500 dolarów w 1990 r. do zaledwie 400 w 1995 r. (według danych szacunkowych) ${ }^{7}$. Ponad $70 \%$ terenów przemysłowych uległo zniszczeniu, co z kolei przełożyło się na ogromne (sięgające 80\%) bezrobocie, które jeszcze zwiększyło się po zdemobilizowaniu żołnierzy ${ }^{8}$. Dla przykładu - w samym tylko Sarajewie straty materialne, powstałe w wyniku kilkuletniego oblężenia miasta, obliczono na ogromną kwotę 14 mld euro. Jak szacowali przedstawiciele Banku Światowego, produkcja przemysłowa spadła do poziomu 5\% z 1990 r., a 70\% obiektów szkolnych uległo zniszczeniu. Do tego dodać należy niezrealizowane umowy handlowe (przykładowo: 500 bośniacko-hercegowińskich firm

i Hercegovina - 15 godina Dejtonskog mirounog sporazuma. Zbornik radova, [ur. H. Bašić, F. Muslić], Sarajevo 2011, s. 250-251.

${ }^{6} \mathrm{M}$. Smajić, Međunarodne organizacije i sigurnost Bosne i Hercegovine u postdejtonskom periodu, Sarajevo 2011, s. 221.

${ }^{7}$ Z. Hurtić, Problems and Prospects of the EU Integration of Bosnia and Herzegovina: Major Macroeconomic Challenges for the Accession Process, „Posebna izdanja Akademije nauka i umjetnosti BiH” 2011, br. 2, s. 153.

${ }^{8}$ M. Søberg, Empowering Local Elites in Bosnia $i$ Herzegovina, „Problems of Post-Communism" 2006, no. 3, s. 50. 
budowlanych miało podpisane zagraniczne kontrakty, zerwane po wybuchu wojny) 9 .

Oprócz ogromnych zniszczeń $\mathrm{w}$ przemyśle, infrastrukturze, rolnictwie itp., fatalne skutki dla gospodarki republiki przyniosła hiperinflacja. Bośniacko-hercegowiński dinar w szybkim tempie tracił na wartości, poza tym nie na całym terytorium kraju był uznawany za środek płatniczy. Właściwie tylko na obszarach znajdujących się pod kontrola rządu w Sarajewie traktowano go jako legalna walutę ${ }^{10}$. Aby przeciwdziałać szybkiej utracie jego wartości, władze w Sarajewie latem 1994 r. przeprowadziły denominację i wprowadziły nowy dinar bośniacko-hercegowiński (BHD), wiążąc go sztywno z marką niemiecką $(1 \text { marka }=100 \mathrm{BHD})^{11}$.

Bezpośrednio po zakończeniu działań zbrojnych (jesienią 1995 r.) bardzo widoczne stało się rozgraniczenie zajętych obszarów. Przedstawiciele trzech narodów konstytutywnych za wszelka cenę starali się podtrzymać swoją odrębność, co miało bezpośrednie przełożenie na gospodarkę, która z trudem podnosiła się z głębokiej wojennej zapaści. Wbrew przyjmowanemu - bardzo często pod presją wspólnoty międzynarodowej - prawu, nasiliło się zjawisko „trybalizacji ekonomii”"12. Każdy z narodów zaczął kształtować własny system ekonomiczno-gospodarczy ( $\mathrm{w}$ tym także proces prywatyzacji), co doprowadziło do licznych, absurdalnych sytuacji, np. w Mostarze utworzono dwie spółki wodociagowe (tak samo nazwane). Jedna $\mathrm{z}$ nich zaopatrywała w wodę muzułmańską część miasta, druga - katolicką. Jak pisze

\footnotetext{
${ }^{9}$ M. Smajić, op. cit., s. 220.

${ }^{10}$ Jedyna, uznawaną przez wszystkie strony konfliktu walutą była marka niemiecka.

${ }^{11}$ F. Čaušević, Makroekonomski okvir..., s. 17.

${ }^{12}$ Idem, Ekonomska liberalizacija, provincijalizacija $i$ otvorenost ekonomije Bosne i Hercegovine, „Forum Bosnae” 2013, br. 63-64, s. 161.
} 
Dragoljub Stojanov: Daytoński podziat Bośni i Hercegowiny na trzy części (Federację, Republikę i Dystrykt) spowodowat jednocześnie podziat dużych przedsiębiorstw. Na przyktad firma $z$ siedziba $w$ Sarajewie (Federacja), która miata swoje oddziaty $w$ Republice Serbskiej lub Dystrykcie Brčko, nie może liczyć na to, że jest wciaż ich wtaścicielem. Ten oddziat należy już do własności państwowej Republiki lub Dystryk$t u^{13}$. Co więcej, jak wskazuja badania przeprowadzone przez Mariję Čuturę z Uniwersytetu w Mostarze, kwestie etniczne (a dokładniej: miejsce wyprodukowania danego towaru) mają także znaczący wpływ na preferencje zakupowe mieszkańców Bośni i Hercegowiny ${ }^{14}$.

Przy tak podzielonej gospodarce, do tego odczuwającej wciąż skutki kilkuletniej wojny, nie było szans na szybkie odrobienie strat. Do chwili obecnej PKB Bośni i Hercegowiny nie osiagną poziomu z $1989 \mathrm{r} .{ }^{15}$, podobnie zreszta jak ma to miejsce w przypadku Czarnogóry czy Serbii. Dla porównania - z krajów powstałych po rozpadzie Jugosławii udało się to tylko najbogatszej i szybko przekierowanej gospodarczo na Unię Europejską (UE) Słowenii (w 1998 r.), stojącej turystyką Chorwacji (w 2005 r.) oraz ominiętej przez działania zbrojne (pomijając późniejszy konflikt z mniejszością albańska) Macedonii (w 2008 r.) $)^{16}$.

${ }^{13}$ D. Stojanov, Bosna i Hercegovina u zamci politike i ekonomije, „Pregled" 2003, br. 1-2, s. 97.

${ }^{14}$ Szerzej na ten temat zob. M. Čutura, Karakteristike potrošackog etnocentrizma i mogućnosti poticanja kupovine domačih proizvoda u Bosni $i$ Hercegovini, „Zbornik radova - Sarajevo Business and Economics Review” 2011, br. 31.

${ }^{15}$ Choć w niektórych źródłach można znaleźć informację, że stało się to już w 2008 r., zob. Z. Hurtić, op. cit., s. 153.

${ }^{16}$ T. Mahmutefendić, Procjena tranzicije u državama nasljednicama Jugoslavije, „Zbornik radova Ekonomskog fakulteta u Istočnom Sarajevu” 2012, br. 6, s. 28. 


\section{Cena pokoju. System polityczny jako bariera w rozwoju gospodarczym}

Gdy jesienią 1995 r. w amerykańskiej bazie lotniczej w pobliżu Dayton przystępowano do rozmów pokojowych, stronom konfliktu, a przede wszystkim przedstawicielom wspólnoty międzynarodowej, zależało na trwałym zakończeniu działań zbrojnych ${ }^{17}$. Udało się wprawdzie osiagnąć zamierzony cel, ale kosztem utworzenia niezwykle skomplikowanego systemu politycznego.

Bośnia i Hercegowina, zgodnie z postanowieniami konstytucji, składa się z dwóch jednostek (entiteti) - Federacji Bośni i Hercegowiny oraz Republiki Serbskiej. Jednak w wyniku nierozstrzygniętego sporu o okolice miasta Brčko utworzono także specyficzny twór - Dystrykt Brčko, formalnie stanowiący kondominium obu jednostek. Federacja jest silnie zdecentralizowana, gdyż składa się z 10 kantonów o szerokim zakresie kompetencji, znacznie różniących się od siebie wielkością i potencjałem ludnościowym. Republika z kolei jest scentralizowana, z samorządem funkcjonującym tylko na poziomie gmin (występujacych również w Federacji). System prawny Bośni i Hercegowiny w niektórych aspektach (szczególnie związanych z wyborami) dyskryminuje tych obywateli państwa, którzy nie należą do jednego z trzech narodów konstytutywnych - najliczniejszych Bośniaków ${ }^{18}$ (do 1993 r. określanych jako Muzułmanie), Serbów (mieszkających przede wszystkim w Republice) oraz najmniej licznych Chorwatów.

${ }^{17}$ W Dayton parafowano porozumienie, a uroczyste podpisanie go miało miejsce w Paryżu w połowie grudnia 1995 r. Więcej nt. rozmów pokojowych zob.: R. Holbrooke, Završiti rat, Sarajevo 1998; W. Walkiewicz, Jugosławia. Państwa sukcesyjne, Warszawa 2009, s. 273-276.

${ }^{18} \mathrm{~W}$ literaturze przedmiotu można spotkać również nazwę Boszniacy (Bošnjaci). 
Organy władzy na niemal każdym szczeblu są nieprawdopodobnie rozrośnięte. Jednak parlament centralny nie jest zbyt rozbudowany, gdyż składa się z dwóch izb o stosunkowo niewielkiej liczbie deputowanych (łącznie 57). Władzę wykonawczą na poziomie państwowym stanowi trzyosobowe Prezydium Bośni i Hercegowiny oraz Rada Ministrów. Do tego m.in. trzeba doliczyć dziewięcioosobowy Sąd Konstytucyjny (trzech sędziów musi pochodzić z zagranicy!). Zarówno w Federacji, jak i w Republice następuje powielenie takiej struktury - w tej pierwszej także kantony maja swoje parlamenty. I to wszystko ma miejsce w państwie, którego liczba ludności spadła poniżej czterech milionów. Nie to jest jednak najbardziej zaskakujace - każdą suwerenną decyzję władz na wszystkich szczeblach może uchylić (i zastapić własna) Wysoki Przedstawiciel Wspólnoty Międzynarodowej (OHR). Urząd ten powołano w Dayton, a po dwóch latach znacznie rozszerzono jego kompetencje, co powoduje, że Bośnia i Hercegowina jest de facto półprotektoratem ${ }^{19}$.

Doskonałą egzemplifikacja absurdalnych wręcz kosztów wprowadzonego po Dayton systemu organów i instytucji władzy niech będzie wypowiedź lorda Paddy'ego Ashdowna, jednego z wysokich przedstawicieli, który $\mathrm{w}$ przemówieniu inauguracyjnym stwierdził m.in.: W kraju, który liczy mniej niż cztery mln mieszkańców, jest 1200 sędziów, 760 członków różnych organów przedstawicielskich, 180 ministrów na różnych poziomach [...]. Jest 14 szefów rzqdów, co oznacza, że jeden premier przypada na każde 300 tys. mieszkańców. Koszty utrzymania tak wielkiego aparatu wtadzy wynosza okoto 1,8 miliardów $K M^{20}$, nie wliczajac $w$ to wydatków na zdrowie,

${ }^{19}$ Więcej na temat specyficznego porządku prawno-konstytucyjnego zob. K. Krysieniel, W cieniu Dayton. Bośnia i Hercegowina między etnokracja i demokracja konsocjonalna, Warszawa 2012.

${ }^{20}$ Czyli marka konwertybilna. 
edukacje czy emerytury. To oznacza, że funkcjonowanie systemu organów władz na wszystkich poziomach kosztuje każdego obywatela okoto $900 \mathrm{KM}$ rocznie, czyli jego trzy przeciętne miesięczne wyptaty ${ }^{21}$. Natomiast w latach 2007-2010 blisko połowę wszystkich środków budżetowych (11,8 z 24,7 mld marek), począwszy od poziomu centralnego, a kończąc na kantonach, przeznaczono wyłącznie na finansowanie działalności administracji publicznej22.

Kolejnym przejawem trudności, które $\mathrm{w}$ innych państwach $\mathrm{w}$ zasadzie nie występuja, był problem wspólnej waluty. Jak już wspomniano, w czasie wojny na obszarze Bośni i Hercegowiny w obiegu znajdowały się różne waluty. Tylko marka niemiecka cieszyła się uznaniem przez wszystkie strony konfliktu. Podobnie rzecz wyglądała po zakończeniu działań zbrojnych, co wymagało szybkiej zmiany. Wprawdzie narzucona w Dayton nowa Konstytucja Bośni i Hercegowiny przewidywała wprowadzenie marki konwertybilnej (KM, symbol międzynarodowy BAM) jako waluty oficjalnej, to jednak brakowało przepisów wykonawczych. Zamiast porozumienia w sprawie wprowadzenia wspólnego pieniądza, Bośniacy, Serbowie i Chorwaci toczyli niekończący się spór m.in. o to, czyje podobizny powinny znaleźć się na banknotach. W takich okolicznościach odpowiednie kroki poczynił ówczesny Wysoki Przedstawiciel, który zażądał od Banku Centralnego podjęcia decyzji. Gdy i to nie pomogło, na mocy specjalnych uprawnień sam narzucił kształt i format banknotów. Wspólną walutę wprowadzono ostatecznie na całym obszarze w czerwcu 1998 r., a obrót bezgotówkowy został dopuszczony we wrześniu $1999 \mathrm{r}^{23}$

${ }^{21}$ D. Stojanov, op. cit., s. 100.

${ }^{22}$ Za 4. godine vlasti za sebe potrošili 11,8 milijardi maraka, 30 IX 2010, http://www.dnevnik.ba.

${ }^{23}$ M. Smajić, op. cit., s. 231. 
Marka konwertybilna jest obecnie sztywno powiąana $\mathrm{z}$ euro ( $\mathrm{w}$ momencie wprowadzania $-\mathrm{z}$ marka niemiecka) - 1 euro to 1,95583 marki. Zgodnie z surowymi regułami, wszystkie marki, znajdujące się w obiegu, mają pełne pokrycie w walucie rezerwowej ${ }^{24}$.

Skomplikowana, silnie zdecentralizowana struktura administracyjna Bośni i Hercegowiny ma swoje odzwierciedlenie w wysokości budżetów, którymi dysponują władze na poszczególnych poziomach. Możliwości finansowe centralnych organów władzy są bardzo ograniczone, a znacznie większymi budżetami dysponuja np. obie jednostki. Przykładowe porównanie wysokości budżetów na przestrzeni kilku lat przedstawia tabela 1 .

Tabela 1. Wysokość budżetów w latach 2003-2008 (w mln KM)

\begin{tabular}{|l|c|c|c|c|c|c|}
\hline $\begin{array}{c}\text { Wyszczególnie- } \\
\text { nie }\end{array}$ & $\mathbf{2 0 0 3}$ & $\mathbf{2 0 0 4}$ & $\mathbf{2 0 0 5}$ & $\mathbf{2 0 0 6}$ & $\mathbf{2 0 0 7}$ & $\mathbf{2 0 0 8}$ \\
\hline $\begin{array}{l}\text { Budżet Bośni } \\
\text { i Hercegowiny }\end{array}$ & 198,0 & 245,0 & 336,8 & 666,5 & 713,2 & 763,1 \\
\hline $\begin{array}{l}\text { Budżet Federa- } \\
\text { cji BiH }\end{array}$ & 1001,5 & 962,8 & 968,2 & 1175,1 & 1150,7 & 1192,6 \\
\hline $\begin{array}{l}\text { Łaczne budżety } \\
\text { kantonów i gmin } \\
\text { w Federacji BiH }\end{array}$ & 1413,5 & 1560,6 & 1667,8 & 1598,2 & 1604,3 & 1658,0 \\
\hline $\begin{array}{l}\text { Budżet Repu- } \\
\text { bliki Serbskiej }\end{array}$ & 991,4 & 996,6 & 995,0 & 1068,6 & 1126,1 & 1186,7 \\
\hline $\begin{array}{l}\text { Eaczne budżety } \\
\text { gmin w Republice } \\
\text { Serbskiej }\end{array}$ & 298,3 & 339,8 & 366,8 & 399,8 & 421,2 & 443,7 \\
\hline $\begin{array}{l}\text { Budżet Dys- } \\
\text { tryktu Brčko }\end{array}$ & 175,0 & 156,0 & 155,0 & 160,0 & 165,0 & 180,0 \\
\hline Budżety lącznie & 4077,7 & 4260,8 & 4489,6 & 5068,2 & 5180,5 & 5424,1 \\
\hline
\end{tabular}

Źródło: F. Čaušević, Ekonomska liberalizacija, provincijalizacija $i$ otvorenost ekonomije Bosne i Hercegovine, „Forum Bosnae” 2013, br. 63-64, s. 159 . 
Niewydolny i podzielony system polityczny $\mathrm{BiH}$ miał także bezpośrednie przełożenie na blokowanie odbudowy i rozwoju ekonomicznego kraju. Niemal całkowity brak wspólnych instytucji rynkowych powodował, że zaczęły się kształtować odrębne systemy gospodarcze. Dopiero presja ze strony UE i zaangażowanie instytucji unijnych przyczyniły się do stopniowego reformowania systemu ekonomicznego państwa.

Począwszy od 2000 r., utworzono w Bośni i Hercegowinie szereg instytucji i organów, których celem była jej stopniowa integracja ekonomiczna. Najpierw powołano do życia Państwową Służbę Graniczną Bośni i Hercegowiny (Držauna granična služba BiH), następnie Skarb Bośni i Hercegowiny (Trezor BiH), giełdy papierów wartościowych w Banja Luce, Sarajewie i Mostarze (i tu można wskazać na silny wpływ czynnika etnicznego). W latach 2000-2003 władze w Sarajewie podpisały umowy o wolnym handlu z dziewięcioma krajami Europy Południowo-Wschodniej, w tym ze wszystkim sasiadami. Wreszcie w połowie $2004 \mathrm{r}$. utworzono - z pomoca Komisji Europejskiej i Agencji Stanów Zjednoczonych ds. Rozwoju Międzynarodowego (United States Agency for International Development, USAID) - Służbę ds. Podatków Pośrednich (Uprava za indirektno oporezivanje). Była to pierwsza instytucja od czasu wojny na poziomie centralnym, która otrzymała uprawnienia do pobierania przychodów o charakterze fiskalnym (cło, akcyza itp.). Zwieńczeniem tego procesu było uchwalenie w 2005 r. ustawy o podatku od wartości dodanej (VAT), która weszła w życie 1 stycznia 2006 r. Wprowadzenie

${ }^{24}$ A. Zaimović, Ekonomija Bosne i Hercegovine - stanje i perspektive, [w:] Država, politika i društvo u Bosni i Hercegovini. Analiza postdejtonskog političkog sistema, prir. D. Banović i S. Gavrić, Sarajevo 2011, s. 206. 
jednolitej stawki podatku na poziomie $17 \%^{25}$ stworzyło możliwość prowadzenia wspólnej polityki fiskalnej na terytorium całego państwa ${ }^{26}$.

Warto choć na chwilę zatrzymać się nad tym ostatnim aspektem, bowiem wyróżnia się on od przeważnie niekorzystnych informacji płynących z Bośni i Hercegowiny. Wprowadzenie podatku VAT i jego skutki można bez wątpienia ogłosić jako wielki sukces, tak rzadki w tym kraju. Już w 2008 r. do budżetu państwa wpłynęło o 60\% podatków pośrednich więcej, niż miało to miejsce w 2005 r., a zamiast oczekiwanych 20 tys. płatników zarejestrowanych było dwa razy tyle. Spośród nich około $99 \%$ uiszczało opłaty w terminie. Można zatem zaryzykować stwierdzenie, że wprowadzenie VAT przyczyniło się do ograniczenia - ale z całą pewnością nie zlikwidowania - tzw. szarej strefy w $\mathrm{BiH}^{27}$.

Mimo sukcesów w ujednolicaniu systemu podatkowego, gospodarka państwa nadal cierpi z powodu podziałów administracyjno-politycznych. Według szacunków niektórych ekonomistów, każdego roku strata spowodowana wykształceniem się odrębnych systemów gospodarczych sięga miliarda euro. Niestety, perspektywa zaoszczędzenia nawet tak olbrzymiej kwoty nie jest $\mathrm{w}$ stanie zachęcić decydentów do podjęcia reform zmieniających skomplikowaną i nieefektywną strukturę wewnętrzną Bośni i Hercegowiny ${ }^{28}$.

${ }^{25}$ Wcześniej w Federacji i Republice obowiązywały różne stopy podatku obrotowego.

${ }^{26}$ F. Čaušević, Bosna i Hercegovina i Evropska unija, „Forum Bosnae” 2013, br. 63-64, s. 181-182.

${ }^{27}$ Z. Hurtić, op. cit., s. 155.

${ }^{28}$ F. Kozić, Demokratija i ekonomija, „BH ekonomski forum” 2012, br. 4 , s. 236. 


\section{Bośnia i Hercegowina jako element gospodarki globalnej. Skutki światowego kryzysu finansowego}

Po zakończeniu wojny w 1995 r. wspólnota międzynarodowa chciała możliwie szybko włączyć Bośnię i Hercegowinę w system gospodarki światowej. Kraj ten stał się członkiem Międzynarodowego Funduszu Walutowego już następnego dnia po uroczystym podpisaniu porozumienia pokojowego w Paryżu, a w nieco ponad trzy miesiące później przyjęto go w poczet członków Banku Światowego ${ }^{29}$. Te symboliczne daty stanowią jednocześnie początek nowych relacji między uczestnikami rynku światowego a zniszczonym przez konflikt zbrojny rynkiem $\mathrm{BiH}$. Rynkiem - co trzeba dodać - który przed wojną tylko do pewnego stopnia stanowił pełnoprawny element światowej gospodarki (w ramach socjalistycznej Jugosławii).

Przez kolejne kilkanaście lat stopniowo i nie bez problemów system gospodarczo-ekonomiczny Bośni i Hercegowiny dźwigał się ze zniszczeń wojennych, stając się jednocześnie elementem rynku europejskiego i światowego. Niosło to ze soba szereg pozytywnych aspektów, ale również uzależniło od tendencji, które akurat wpływały na gospodarkę globalną. Jednym z nich okazał się światowy kryzys finansowy, który odcisnął swoje piętno pod koniec pierwszej dekady XXI w.

Czołowi przedstawiciele władz, odpowiedzialni za politykę gospodarczą i finansową (w tym np. szef rządu, ministrowie finansów i skarbu oraz premierzy obu jednostek), jeszcze w trzecim kwartale 2008 r. zapewniali, że kryzys finansowy nie będzie miał wpływu na sytuację w Bośni i Hercegowinie ${ }^{30}$. Co ciekawe, przemawiał przez nich nie tylko „obowiązkowy”, polityczny

${ }^{29}$ F. Čaušević, Makroekonomski okvir..., s. 18.

${ }^{30}$ Idem, Mogućnosti oporavka bosanskohercegovačke ekonomije i regiona Zapadnog Balkana, „Forum Bosnae” 2013, br. 63-64, s. 264. 
optymizm, ale i pewne racjonalne przesłanki. Bośnia i Hercegowina bowiem, podobnie jak znaczna część krajów dopiero przechodzacych tranzycję, nie była aż tak silnie zwiazana eksportem z partnerami zagranicznymi (upłynał zbyt krótki czas od rozpoczęcia procesu integracji gospodarczej, brakuje towarów, które miałyby szanse podbić obce rynki). Można było zatem mieć nadzieję, że kryzys albo ominie Sarajewo, albo, co najwyżej, osłabi tempo wzrostu. Tymczasem nie przewidziano, że, po pierwsze - miejscowi inwestorzy poddadzą się ogólnoświatowej panice i zaczną wycofywać się z giełd, a po drugie - silne okażą się inne czynniki, rzutujące negatywnie na rozwój: spowolnienie reform gospodarczych, wstrzymanie prywatyzacji państwowych przedsiębiorstw oraz opóźnienia w przebudowie bardzo obciążającego budżet systemu emerytalnego ${ }^{31}$.

Fatalne następstwa światowego kryzysu finansowego uderzyły w rynek bośniacko-hercegowiński w ostatnim kwartale 2008 r. Znacznie spadł poziom aktywności gospodarczej, co niekorzystnie wpłynęło na i tak bardzo wysokie bezrobocie. Osiagnęło ono w czerwcu 2009 r. niezwykły poziom, gdyż zarejestrowano $41,6 \%$ bezrobotnych (40,6\% w grudniu roku poprzedniego). Trzeba jednak dodać, że ten astronomiczny wręcz odsetek pozostających bez pracy jest poddawany w watpliwość przez specjalistów, krytykujących przyjętą w Bośni i Hercegowinie metodologię jego obliczania. Według danych Międzynarodowej Organizacji Pracy (International Labour Organization, ILO), faktycznie w 2009 r. poszukiwało zatrudnienia $24,1 \%$ - reszta spośród oficjalnie zarejestrowanych bezrobotnych pracowała „na czarno" ${ }^{32}$.

Pod koniec 2008 r. niemal wszystkie dane ekonomiczne wskazywały na pierwsze po 1995 r. załamanie gospodarcze

${ }^{31}$ S. Pačaric, Globalna financijska kriza - Bosna i Hercegovina u fokusu, „Forum Bosnae” 2009, br. 47, s. 131.

${ }^{32}$ Izvještaj o napretku Bosne i Hercegovine u 2009. godini, Brisel, $14 \mathrm{X}$ 2009, s. 25-26. 
w BiH. Produkcja przemysłowa, eksport i import, inwestycje oraz popyt wewnętrzny zanotowały wyraźny spadek. Kryzys gospodarczy osiagnął najgłębszy poziom w 2009 r., gdy 70 tys. osób straciło pracę, eksport spadł o 21\%, a import aż o $26 \%$. Gwałtownie obniżyły się inwestycje zagraniczne, podobnie jak rezerwy walutowe Banku Centralnego Bośni i Hercegowiny. Wzrost PKB osiagnął wartość ujemną $(-2,9 \%)$ - zaczęła się recesja. Aby uratować kraj przed problemem niewypłacalności, konieczne było podpisanie porozumienia z Międzynarodowym Funduszem Walutowym, który zaoferował Sarajewu pożyczkę w wysokości 1,2 mld dolarów ${ }^{33}$.

Tabela 2. Wybrane wskaźniki gospodarcze w Bośni i Hercegowinie

\begin{tabular}{|c|c|c|c|c|c|c|c|c|c|c|c|}
\hline & 1996 & 1997 & 1998 & 1999 & 2000 & 2002 & 2004 & 2006 & 2008 & 2009 & 2010 \\
\hline $\begin{array}{l}\text { PKB } \\
\text { (mld } \\
\text { euro) }\end{array}$ & & & & 4,9 & 5,5 & 6,5 & 8,1 & 9,8 & 12,6 & 12,3 & 13,0 \\
\hline $\begin{array}{l}\text { Realna } \\
\text { stopa } \\
\text { wzrostu } \\
\text { PKB (\%) }\end{array}$ & 86,0 & 37,0 & 10,0 & 10,0 & 5,5 & 5,5 & 6,0 & 6,2 & 5,7 & $-2,9$ & 0,5 \\
\hline $\begin{array}{l}\text { PKB per } \\
\text { capita } \\
\text { (euro) }\end{array}$ & & & & 1385 & 1449 & 1713 & 1953 & 2387 & 3287 & 3182 & 3200 \\
\hline $\begin{array}{l}\text { Poziom } \\
\text { bezro- } \\
\text { bocia \% }\end{array}$ & & & & 39,3 & 39,7 & 40,9 & 43,2 & 31,9 & 23,4 & 24,1 & 27,2 \\
\hline
\end{tabular}

Źródło: B. Tihi, Globalna ekonomska kriza, političke nesigurnosti i mogućnosti za reforme u Bosni i Hercegovini, [w:] Međunarodni simpozij Bosna i Hercegovina - 15 godina Dejtonskog mirounog sporazuma. Zbornik radova, [ur. H. Bašić, F. Muslić], Sarajevo 2011, s. 259; http://www.bhas.ba.

${ }^{33}$ B. Tihi, op. cit., s. 250. 
Na tle ogólnie złej sytuacji gospodarczej Bośni i Hercegowiny może zastanawiać względnie dobra kondycja systemu bankowego w tym państwie, szczególnie w kontekście światowego kryzysu finansowego. Sensownym wytłumaczeniem tego zjawiska jest fakt, że sektor bankowy okazał się jedynym, w którym w pełni przeprowadzono proces restrukturyzacji. Prywatyzacja w tym przypadku nie miała charakteru „kuponowego”, w oparciu o vouchery, ale pojawili się inwestorzy zagraniczni, przynosząc ze sobą „świeże" fundusze know how. Do tego uchwalono (też sytuacja wyjątkowa) odpowiednie ramy prawne, tworząc nowoczesny system nadzoru nad działalnościa sektora bankowego. I wreszcie ostatni wyjątek - banki w Bośni i Hercegowinie są w znacznie mniejszym stopniu podzielone pod względem etnicznym, gdyż mają oddziały na obszarze całego kraju, a nie tylko w Federacji czy Republice ${ }^{34}$.

\section{„Na garnuszku” wspólnoty międzynarodowej}

Bezpośrednio po zakończeniu wojny i podpisaniu porozumienia pokojowego, Bośnia i Hercegowina właściwie w żadnym wymiarze, w tym także gospodarczym i ekonomicznym, nie była w stanie funkcjonować samodzielnie. W takich okolicznościach przedstawiciele wielu państw i organizacji międzynarodowych zobowiazali się do przekazania pomocy finansowej podzielonemu wewnętrznie i bardzo zniszczonemu krajowi. Wstępne oceny Banku Światowego przewidywały konieczność pilnego zapewnienia 5,1 mld dolarów - tylko na niezbędne potrzeby mieszkańców. W trakcie pobytu roboczego zespołu z Banku Światowego przygotowano projekty odbudowy m.in. najważniejszych

${ }^{34}$ E. Čengić, Bosna i Hercegovina. Put ka Evropskoj uniji, Sarajevo 2010, s. 155 . 
zakładów pracy i infrastruktury, koniecznej do transportu materiałów, aby można było jak najszybciej rozpocząć produkcję ${ }^{35}$.

Dla zgromadzenia potrzebnych środków, na odbudowę kluczowych elementów bośniacko-hercegowińskiej gospodarki, zostało zorganizowanych pięć konferencji donatorów. Pierwsza z nich odbyła się już pod koniec grudnia 1995 r., ostatnia w 1999 r. Ogółem brało w nich udział 48 krajów oraz 14 organizacji międzynarodowych, które przekazały łącznie 3,7 mld dolarów na inwestycje w infrastrukturę i rozwój ekonomiczny ${ }^{36}$.

Skala tej pomocy była ogromna. Jak się szacuje, tylko do 2001 r. wspólnota międzynarodowa przekazała Bośni i Hercegowinie - w różnej formie - od 46 do 53 mld dolarów ${ }^{37}$. Niestety, wskutek powszechnej korupcji i braku przejrzystych reguł, spośród przekazanych bezpośrednich funduszy pomocowych „zniknął” co najmniej miliard dolarów ${ }^{38}$.

Całkowita pomoc dla Bośni i Hercegowiny osiagnęła - oceniając ją przez pryzmat stosunkowo niewielkiej liczby ludności - olbrzymią skalę, przez pewien czas najwyższy poziom na świecie. Według niektórych obliczeń, od 1996 r. do 2007 r. na przeciętnego mieszkańca tego państwa przypadało około 300 dolarów, podczas gdy - dla porównania - od 2002 r. w Afganistanie pomoc międzynarodowa oscylowała na poziomie 65 dolarów na osobę rocznie ${ }^{39}$. Dopiero międzynarodowa pomoc dla Timoru Wschodniego okazała się wyższa (w przeliczeniu na mieszkańca).

Spośród wszystkich donatorów największym jest Unia Europejska, która pierwsze środki dla Bośni i Hercegowiny przeznaczyła już w 1991 r. (wtedy jako Europejska Wspólnota

${ }^{35}$ M. Smajić, op. cit., s. 213.

${ }^{36}$ Ibidem.

${ }^{37}$ D. Stojanov, op. cit., s. 93.

${ }^{38}$ P.C. McMahon, J. Western, The Death of Dayton. How to Stop Bosnia from Falling Apart, „Foreign Affairs” 2009, vol. 88, no. 5, s. 70.

${ }^{39}$ Ibidem. 
Gospodarcza), gdy kraj ten staną w obliczu poważnego kryzysu, dotyczącego przyszłości. Początkowo była to pomoc o charakterze stricte humanitarnym, w wysokości około $500 \mathrm{mln}$ (późniejszych) euro. Od 1996 r. BiH uzyskała dostęp do programu PHARE, a w następnych latach do kolejnych programów unijnych, po części utworzonych z myślą o krajach Bałkanów Zachodnich (CARDS, ISPA, SAPARD - zamienione po 2007 r. na IPA). Dodać należy, że także inne państwa tego regionu korzystały (i dalej korzystaja) z różnych form unijnej pomocy, a jej wysokość zależy w dużej mierze od stopnia zaawansowania w procesie integracji ${ }^{40}$.

Istotnym impulsem dla poszerzenia strumienia środków pomocowych było rozpoczęcie w 1999 r. Procesu Stabilizacji i Współpracy (Stabilisation and Association Process, SAP), którym objęto państwa Europy Południowo-Wschodniej, w tym BiH. Dzięki niemu stało się możliwe stopniowe wchodzenie do kolejnych programów unijnych, zmierzających do zacieśnienia współpracy. Końcowym akordem Procesu miało być zawarcie Porozumienia o Stabilizacji i Stowarzyszeniu (Stabilisation and Association Agreemeent, SAA). Umowę tę podpisano - mimo wielu przeszkód, głównie natury politycznej - w czerwcu 2008 r..$^{41}$ Niestety, niejako „za karę” za wstrzymanie niezbędnych dla pogłębiania integracji reform konstytucyjnych, do dziś nie weszła ona w pełni w życie, bo nie ratyfikowały jej odpowiednie organy UE. Wciąż obowiązuje tymczasowe porozumienie, dzięki któremu wymiana handlowa Bośni i Hercegowiny z krajami unijnymi została zliberalizowana. Unia, m.in. dzięki temu, stała się głównym partnerem handlowym Sarajewa, gdyż przypada na nią ponad połowa wymiany.

${ }^{40}$ A. Zaimović, A. Pušina, Programi Evropske zajednice za Bosnu i Hercegovinu, „Zbornik radova Ekonomskog fakulteta u Sarajevu” 2009, br. 29, s. $366-367$.

${ }^{41}$ A. Zaimović, op. cit., s. 219-220. 


\section{Zakończenie. Perspektywy rozwoju sytuacji}

Po okresie stabilnego wzrostu w latach 2000-2008, PKB Bośni i Hercegowiny w 2009 r. obniżył się prawie o 3\%, w następnym roku minimalnie wzrósł $(0,5 \%)$, podobnie jak w 2011 r. W 2012 r. nie zmienił się (według niektórych źródeł spadł - od 0,15\% do nawet 0,5\%), co powoduje, że po pięciu latach trwania światowego kryzysu finansowego - PKB Bośni i Hercegowiny nie osiagnał poziomu sprzed jego rozpoczęcia ${ }^{42}$. Dopiero (wciąż nieoficjalne dane) za 2013 r. oraz prognozy na 2014 r. dają szansę powrotu na ścieżkę niewielkiego rozwoju gospodarczego.

Starając się podsumować niełatwą sytuację gospodarczą Bośni i Hercegowiny, można wskazać następujące, najważniejsze jej cechy:

a) znaczacy udział w PKB maja te sektory gospodarki, które charakteryzują się niskim poziomem innowacyjności (handel i produkcja rolna); ponadto dynamicznie rośnie udział podatków w strukturze produktu narodowego;

b) wysoka stopa rejestrowanego bezrobocia (najwyższa $\mathrm{w}$ regionie, znacznie przewyższająca dane $\mathrm{z}$ ogarniętej kryzysem Grecji), połączona ze stosunkowo wysokim poziomem przeciętnego wynagrodzenia (wyższy jest tylko w sassiedniej Chorwacji); wpływa to na powiększenie się tzw. szarej strefy;

c) szczególnie niebezpieczny dla stabilności państwa jest wysoki poziom bezrobocia młodych; stanowią oni tylko 12,7\% zatrudnionych, a wśród wszystkich zarejestrowanych bezrobotnych, aż $58 \%$ to młodzi ludzie;

d) bardzo niskie emerytury - najniższe (oprócz Kazachstanu) wśród krajów przechodzących tranzycję;

e) wysoki poziom korupcji;

${ }^{42}$ T. Slijepčević [et al.], op. cit., s. 25. 
f) stała nadwyżka importu nad eksportem, co skutkuje rosnącym poziomem deficytu handlowego; równie negatywna jest struktura eksportowanych dóbr, na które głównie składaja się półprodukty, surowce naturalne i produkty rolne, natomiast import obejmuje np. dobra wysoko przetworzone $\mathrm{e}^{43}$.

Ogólnie rzecz biorąc, sytuacja gospodarcza i ekonomiczna Bośni i Hercegowiny jest ciagle zła. Miliardy euro pomocy ze strony wspólnoty międzynarodowej nie przełożyły się na znacząca poprawę warunków życia mieszkańców, sfrustrowanych permanentnym kryzysem i wszechogarniająca korupcją ${ }^{44}$ wśród rządzacych na każdym szczeblu.

Poziom niezadowolenia przekroczył krytyczny próg na początku 2014 r., gdy po zamknięciu jednej z fabryk w Zenicy, w kilkudziesięciu miastach Bośni i Hercegowiny doszło do masowych protestów, zakończonych podpaleniem niektórych siedzib najwyższych organów władzy państwowej (w tym budynku Prezydium Bośni i Hercegowiny) oraz licznymi dymisjami na różnych szczeblach władzy. Bodaj po raz pierwszy od 1995 r. wystapienia te nie miały podłoża etnicznego, gdyż protesty odbywały się na całym obszarze kraju (w większym stopniu w bardziej uprzemysłowionej Federacji). Tym samym można dojść do smutnej konstatacji, że fatalna sytuacja gospodarcza i ekonomiczna przysłoniła dotychczasowy problem numer jeden Bośni i Hercegowiny, czyli głębokie podziały etniczne. Nie jest to jednak powód do dumy, a raczej poważny problem dla władz tego państwa.

${ }^{43}$ K. Hodžić, Makroekonomsko konvergiranje Bosne i Hercegovine Evropskoj Uniji: neizujesnost i dugotrajnost procesa, „Forum Bosnae” 2008, br. 43 , s. $129-130$.

${ }^{44}$ Bośnia i Hercegowina przez kilkanaście lat była określana - według raportu Transparency International - najbardziej skorumpowanym krajem w regionie. Przestała nim być w 2009 r. tylko dlatego, że po raz pierwszy uwzględniono w raporcie Kosowo. 